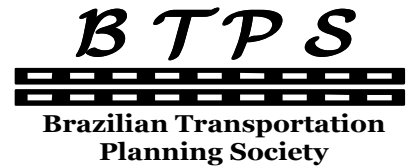

Planning Society

\author{
Journal of Transport Literature \\ Vol. 8, n. 2, pp. 178-200, Apr. 2014 \\ Research Directory
}

\section{JTL|RELIT}

www.transport-literature.org ISSN 2238-1031

\title{
Analysis of rail yard and terminal performances
}

\author{
[Análise do pátio ferroviário e do desempenho de terminais]
Marin Marinov*, Leonardo Di Giovanni, Giulia Bellisai, Julian Clevermann, Anastasia Mastellou, Diogo Victória, Lalka Deleva

\begin{abstract}
Newcastle University - UK, Sapienza Universita di Roma - Italy, Sapienza Universita di Roma - Italy, Technische Universität Dortmund - Germany, Athens University of Economics and Business - Greece, Instituto Superior Técnico - Portugal, Todor Kableshkov University of Transport - Bulgaria
\end{abstract}

Submitted 30 Jan 2013; received in revised form 31 Jul 2013; accepted 31 Jul 2013

\begin{abstract}
One of the latest trends in the transport field is the increasing interest for the rejuvenation of the railway. It is considered to be a logical consequence of the gradual switch towards a more sustainable future in transports. Terminals and stations are considered to be the junction points between the various lines that constitute the railway network and can simply be described as points of arrival, departure and interchange of passengers or commodities. The most commonly used indicators that measure the level of their performance are time and cost. This study aims at exploring possible improvements that could be implemented to the infrastructure and the operation of terminals and stations in order to increase the efficiency level. Firstly, drawing upon grounded theory about rail infrastructure and terminals, a description is conducted, followed by a comparative analysis of the different types of existing terminals and stations. Secondly, the suggested improvements are presented in accordance with their time frame completion. The main contribution of this study is to illustrate the high significance of terminals, stations and yards, acknowledging them as crucial parts of the railway network, because as characterized and demonstrated in this study, their performance are key factors to the whole network performance, making the identification of their critical points and respective possible solutions, the final objective of this paper. In addition to this, emphasis is given to the need of improving and developing the existing terminal infrastructure and operations.
\end{abstract}

Key words: railways, efficiency, rail yards, rail stations, terminals.

\section{Resumo}

Uma das últimas tendências na área de transportes é o crescente interesse na modernização da rede ferroviária. Este passo é considerado como uma consequência lógica da mudança progressiva para um futuro mais sustentável em transportes. São considerados terminais e estações os pontos de convergência entre as várias linhas que constituem a rede ferroviária e podem ser simplesmente descritos como pontos de partida, chegada e circulação de passageiros ou mercadorias. Os indicadores mais comuns utilizados para medir os seus níveis de desempenho são o tempo e o custo. Este estudo pretende explorar possíveis melhorias que podem ser implementadas na infraestrutura e na operação de terminais e estações, a fim de melhorar os seus níveis de eficiência. Em primeiro lugar, e baseando-se na teoria fundamentada nos dados, é feita uma descrição, seguida de uma análise comparativa dos diferentes tipos de terminais e estações existentes. Em segundo lugar, são apresentadas as melhorias sugeridas, de acordo com o seu período de implementação. Tem este estudo como principal contribuição, ilustrar a alta importância dos terminais, estações e pátios, uma vez que estes são considerados como partes fundamentais da rede ferroviária. É também dada grande ênfase à necessidade de melhorar e desenvolver a infraestrutura dos terminais existentes, assim como as operações envolvidas.

Palavras-Chave: transporte ferroviário, eficiência, pátios, estações, terminais.

*Email: marin.marinov@ncl.ac.uk.

\section{Recommended Citation}

Marinov, M., Giovanni, L., Bellisai, G., Clevermann, J., Mastellou, A. and Victória, D., Deleva, L. (2014) Analysis of rail yard and terminal performances. Journal of Transport Literature, vol. 8, n. 2, pp. 178-200.

- JTL/RELIT is a fully electronic, peer-reviewed, open access, international journal focused on emerging transport markets and published by BPTS - Brazilian Transport Planning Society. Website www.transport-literature.org. ISSN 2238-1031. 


\section{Introduction}

Rail terminals and yards are important parts of the railway network because of their function to ensure the mobility of passengers and freight. Indeed, almost all transit times are used for transhipment and shunting operations. Typical processes at these points of the railway network, should be optimised and have to be continuously improved. Continuous improvements are necessary because of the change of materials which are transported. In the past, most of the loads were heavy goods. But nowadays the majority of goods transported by train are light-weighted and palletised. This takes an effect on the used trains and terminals, but also offers new chances to develop ideas for a new terminal design.

In the first part of this paper are presented the different existing types of terminals, defining main differences between passenger stations and passenger terminals as well between different types of intermodal terminals and freight yards. For each type, layouts are represented and indicators for objective evaluation in quantitative terms are propose, being the most commonly used indicators that measure the level of their performance, time, costs, and others that contain physical characteristics of the layout as capability, length of operating rails or approximate area. After describing the different types of terminals that serve passengers and freight and regarding the change of the transported goods by train, short, medium and long term improvement possibilities are explored in the second part of this paper, in order to outlook aspects of a future terminal.

This paper aims to show the right direction to follow in the railway field, after assessing strengths and weaknesses of rail terminals and freight yards, by advising the most opportune solutions to improve the efficiency of terminals and yards, using new technologies or different methodologies. Because there is no single solution to achieve this goal, the possible solutions will refer to time periods of application and different needs of investment, depending on the characteristics of innovation, latest technologies and different proposed methods. In particular, with regard to the long term period, the idea about the creation of a unique technologically advanced station that simultaneously handles the transport of passengers and goods is promoted. 


\section{Rail Terminal \& Yards}

\subsection{Passenger Stations}

The main goal of stations is to serve passengers, making this a physical place where a train can stop safely and embark and disembark passengers. Since trains have to stop at the stations, they have to be planned so that these stops will not disrupt the system, meaning that the main stations has to grant not only the embarking and disembarking of passengers, but also meeting/overtaking operations of trains as well shunting for variation of train composition (Teixeira, 2011).

With this in mind, it is easy to understand the existence of three basic topologies of stations, where every station is as follows or a combination of:

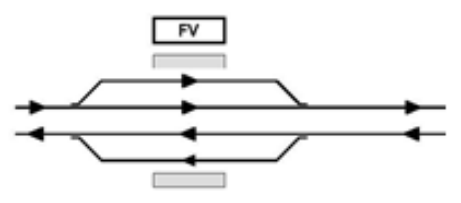

Running station

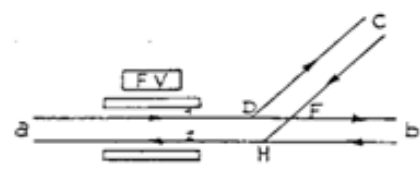

Junction station

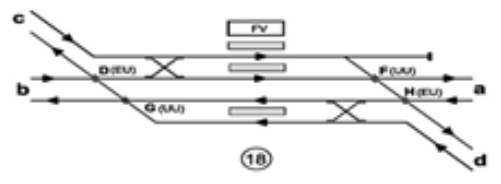

Crossing station

Figure 1 - Topologies of stations (Ricci, 2012)

The only difference between transit station and a terminal station is that this last, is a rail station where it stands in the end of the line. These stations have the particularity of being named as terminus station, assuming then the terminal station as the whole infrastructure that can also provide other services. This terminus stations can be as follow:
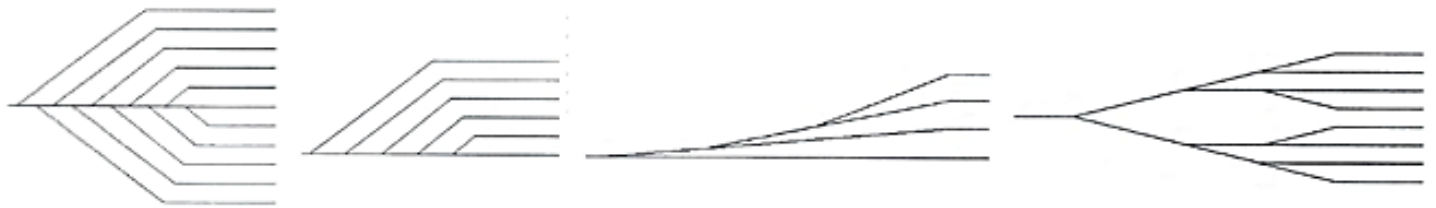

Figure 2 - Topologies of terminus stations (Teixeira, 2011)

The capacity of a station is the maximum amount of trains the station can process, therefore it is important to minimise the time each train takes to enter the station, perform the planned operation (stops, overtaking, manoeuvres) and exit the station (Ricci, 2012). It is then 
essential to plan the layout of stations, according to the service it will provide, taking account not only the actual traffic but also the future traffic.

The basic elements which have to be considered in a passenger station are the number and the length of main lines and also the ones for park and manoeuvring, which are a key feature in main stations, where trains start and end their journeys. The number, length and width of platforms are also an important and key feature to be taken, as well their height, because each type of train has different characteristics. Another aspect to be reflected when designing a station is their accessibility, not only on the inside of the station itself (corridors, stairs, escalators, lifts) but also on the outside, where the intermodality has to be considered (Teixeira, 2011).

A usual way to calculate the width of a platform should be by making possible to clear $70 \%$ of the passengers in the first 3 minutes. In order to do this, it is necessary to know how many passengers we are dealing with. A possible formula to calculate the number of passengers is:

$$
P=1.1 \times 0.8 \times P_{c}
$$

Where, $\quad P$ - number of passengers

$$
\begin{aligned}
& 1.1 \text { - consider } 10 \% \text { of non-travellers } \\
& 0.8-80 \% \text { of occupancy of the train } \\
& P_{C} \text { - number of seats on the train (Teixeira, 2011) }
\end{aligned}
$$

So it will be,

$$
P=0.88 \times P_{c}
$$

Knowing this standardised number of passengers, the width of the platform could be calculated as follow:

$$
w=\frac{70 \% \times 0.88 \times P}{50 \times 3 \times S}
$$

Where, $50 \times 3$ means a 50 passengers/meter $3 \mathrm{~min}$ and $S$ the number of exits (Teixeira, 2011). 
To this width, it has to be added a respect area so the passengers can stay away from the edge of the platform in safety. Usually the platform widths are between 10 to 12 meters in contrast with the old stations where they are closer to 5 to 8 meters (Teixeira, 2011).

About some usual times that operators require to have in stations, they depend on which kind of operation the trains are involved. For example, if it is a start of a service, it is convenient the train to enter station 20 minutes before departure. On the other hand, when a train arrives at a terminal station, it should hold on for about 15 minutes. When it is a combination of both, arrival and then departure (of another service), it is called turn-a-round time, and can be around 45 minutes (Teixeira, 2011).

Once again, these times depend on the type of the train and its characteristics, the modus operandi of the operator and also if it is a transit or a terminal stop. For example in Germany the usual times are as shown in Table 1.

Table 1 - Dwell times at different types of German station (Clausen, 2011)

\begin{tabular}{c|cc} 
Dwell time (minutes) & Transit Station & Terminal Station \\
\hline Long distance train & $2-3$ & $4-6$ \\
Short distance train & $1-2$ & 4 \\
Urban train/tram & 0.5 & $2-3$
\end{tabular}

\subsubsection{Comparison between Transit and Terminal Stations}

There are two major stations in Lisbon, Portugal, that serve long-distance, short-distance and urban trains. "Oriente" is a transit station that is closely located to the city limits and has a big offer in terms of intermodality. "Oriente" has interface with the subway and a Bus Terminal and it is also connected to a shopping centre. "Santa Apolónia" is a terminal station located in city centre and has interface with the subway and it is near to a cruise ship dock. "Oriente" has 8 platforms and it is used by 784,534 passengers per month, while "Santa Apolónia" has 7 platforms and handles 405,528 passengers monthly (REFER - Rede Ferroviária Nacional, EPE, 2008). 
Sticking to these examples, and assuming they are similar in a number of platforms and in their surroundings, it is obvious that transit stations can have better performances than the ones with terminal station. In this case of comparison, the difference of number of passengers it is around two times. This could be explained as terminal station can only provide service from one way of the rail network in contrast with the transit station, which can provide service in both ways, making this type of station potentially more efficient in terms of number of passengers transported. Despite this explanation may be true, it is important to know this is a simple case of comparison and cannot make a rule out of it, as there are numerous other factors that can significantly change or explain this numbers.

\subsection{Intermodal Terminals}

Intermodality occurs when two or more modes of transportation meet for the purpose of exchanging cargo - whether directly or through intermediate storage (Feldman et. al., 1996) define the concept as follows:

"In its broadest interpretation, intermodality refers to a holistic view of transportation in which individual modes work together or within their own niches to provide the user with the best choices of service, and in which the consequences on all modes of policies for a single mode are considered" (Feldman et. al., 1996). Intermodality originated in maritime transportation, with the development of the container in the late 1960's and has since spread to integrate other modes (Middendorf, 1998).

Intermodality offers the opportunity to combine modes and find a less costly alternative than a unimodal solution. It is also linked with a higher average value of the cargo being carried since intermodal transportation is linked with more complex and sophisticated commodity chains. As a result, the efficiency of contemporary transport systems rests as much on their capacity to route freight than on their capacity to tranship it, but each of these functions have a cost that must be reduced (Rodrigue et al., 1998).

Intermodal exchange may not be the only function performed at an intermodal terminal, or even the primary one. All that is required for a freight terminal to be an intermodal terminal is that it has the necessary space and equipment to receive cargo by one mode of transportation and ship it out by a different mode. In between the inbound and outbound movement, the 
cargo may be consolidated with other incoming cargo of the same type, separated into smaller outbound shipments, or directly transferred between two modes as part of a seamless intermodal shipment (Middendorf, 1998).

In the following table are presented the different types of intermodal transport that are going to be analysed, as well as the load units that are used in each type.

Table 2 - Typologies of intermodal transport (Musso, 2010)

\begin{tabular}{c||c} 
Specialisations of intermodal terminals & Load units used \\
\hline \hline Sea-rail combined terminals & Maritime containers \\
Road-rail combined terminals & Swap bodies or Semitrailers
\end{tabular}

Table 3 - Characteristics of an intermodal terminal according to dimension (Musso, 2010)

\begin{tabular}{|c|c|c|c|}
\hline Terminal & Small & Medium & Large \\
\hline Capability & $\begin{array}{c}\text { 70/80 UTI every } \\
\text { day }\end{array}$ & $\begin{array}{c}\text { 140/150 UTI every } \\
\text { day }\end{array}$ & $\begin{array}{c}\text { More than } 250 \text { UTI } \\
\text { every day }\end{array}$ \\
\hline Moving vehicles & $\begin{array}{c}1 \text { self-propelled } \\
\text { crane with } \\
\text { spreader }\end{array}$ & $\begin{array}{c}\text { - 1/2 self-propelled } \\
\text { cranes } \\
\text { - } 1 \text { self-propelled } \\
\text { forklift }\end{array}$ & $\begin{array}{c}\text { - } 1 \text { gantry crane } \\
\text { with } 10 \\
\text { connections } \\
\text { - } 1 \text { gantry crane } \\
\text { with } 6 \text { connections }\end{array}$ \\
\hline $\begin{array}{c}\text { Length of operating } \\
\text { rails }\end{array}$ & $250 \mathrm{~m}$ & $400 \mathrm{~m}$ & $>550 \mathrm{~m}$ \\
\hline Approximate area & $10,000-15,000 \mathrm{~m}^{2}$ & $40,000-50,000 \mathrm{~m}^{2}$ & $>70,000 \mathrm{~m}^{2}$ \\
\hline Other features & - & $\begin{array}{l}\text { - Tractor to handle } \\
\text { the semitrailers } \\
\text { - Office building }\end{array}$ & $\begin{array}{l}\text { - Storage capacity: } \\
\text { 2,000 containers } \\
\text { - Many offices }\end{array}$ \\
\hline
\end{tabular}


The physical characteristics, complexity, and other attributes of intermodal freight terminals vary greatly. Some intermodal terminals are relatively small and almost ad hoc in nature, while others are large and involve a considerable amount of infrastructure. As an aid in identifying and classifying intermodal terminals and thereby gaining a better understanding of the concept of intermodality in its various forms, five features or characteristics of intermodal terminals are especially useful: the pairs of modes which the terminal directly or indirectly connects, the types of cargo or the specific commodities which the terminal handles, the types of intermodal transfers for which the terminal is designed (direct, short-term storage, or longterm storage), whether the terminal is privately or publicly owned, and whether use of the terminal is open or restricted relative to either shippers or carriers (Middendorf, 1998).

\subsubsection{Road-Rail combined Terminals}

The capacity of a CT terminal is determined by a couple of factors, which can only partly be influenced by the local terminal manager. The primary influences are the position of the terminal within the rail and road network, the size and shape of the real estate, the length of the handling tracks, and the number and capabilities of the handling equipment. In recent years a modular shape of terminals has been developed which is made of:

- one - or better double-sided rail access, where signalling allows for entry with momentum and direct departure of the train by the main line traction unit;

- three to five "train long" (length can vary between countries) handling or transhipment tracks, with rail-mounted gantry cranes (RMG), two to three interim storage or buffer lanes, one loading and one driving lane;

- road side access with check- in / check- out area (gate) and sufficient parking space;

- $\quad$ one typical module of that kind should be able to handle about 120-150,000 loading units p.a. (rail-in and rail-out handlings). While a doubling or even trebling could improve the capacity accordingly.

One typical module of that kind should be able to handle about 120-150,000 loading units p.a. (rail-in and rail-out handlings). While a doubling or even trebling could improve the capacity accordingly (Intermodal terminal, 2012). 


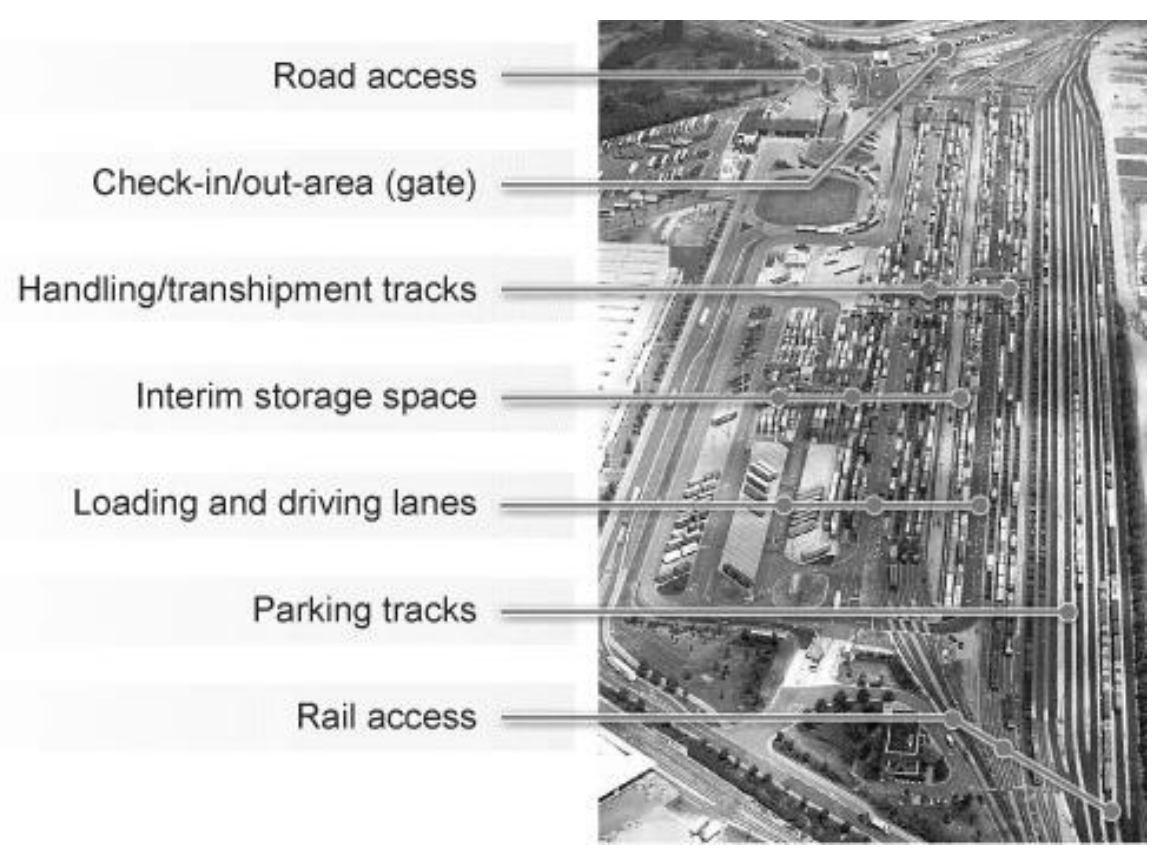

Figure 3 - Road-rail terminal module (Intermodal Terminals, 2012)

\subsubsection{Sea-Rail combined Terminals}

The freight terminal ports can be differentiated in many different types, but the one that is most commonly used is the container terminal (Lo-Lo).

Lo-Lo (Lift on - Lift off) vessels can transport a range of different products as a result of their flexible cargo space, container capacity and on board cranes. Lo-Lo cargo is containerized cargo that must be lifted on and off vessels and other vehicles using handling equipment. A Lo-Lo operation is when cargo is loaded and discharged over the top of the vessel using cranes or derricks. Lo-Lo vessels load and unload cargo at (Ro-Ro) ports, Lo-Lo ports and at unserviced jetties, using its own cranes. Self-geared Lo- Lo type vessels are loaded and unloaded by a crane, which lifts cargo to a specific location on the Lo-Lo ship. The cargo is loaded pursuant to a specific plan that is necessary in order to balance the Lo- Lo ships as they are not equipped with ballast-adjusting mechanisms (Global Security, 2012).

This type of terminals are now associated with the major volumes of traffic by sea and take on crucial importance the strategic and economic organization of shipping. From a general point of view, they are intended to serve ships ranging in size from about 100 meters to more than 300 meters length and flow rates ranging from 300 to 500 TEUs (feeder ships that perform services for the collection and distribution in confined basins) to 8,000-10,000 TEU (ocean 
liners of the last generation). The longitudinal development of such terminals is considerable in relation to the need to simultaneously berth at the quay side for ships large size.

The main functional components of such a type of terminal are:

- Reduced equipment for loading and unloading;

- Large areas on which to stand and the means for transportation lanes independent;

- Boarding ramps ranging in size between 3.5 and 4 meters lane;

- Signs and road markings for traffic rules and stop.

\subsubsection{Comparison among different types of Intermodal Terminals}

The table below presents the main characteristics of the most important intermodal terminals that have an interface with rail.

Road-Rail terminals are identified as:

- National and International rail and road traffic: swap bodies and maritime containers;

Sea - Rail terminals are identified as:

- Traffic with maritime origins and destinations with a change of transport mode for forwarding by rail to domestic and international destinations for long distance: predominance of sea containers over swap bodies

In addition it should be noted that Air - Rail terminals are beyond the scope of this studies and therefore are not included in the analysis. 
Table 4 - Characteristics of intermodal terminals according to the typology (Musso, 2010)

\begin{tabular}{|c|c|c|c|c|c|c|c|c|}
\hline & \multicolumn{2}{|c|}{$\begin{array}{c}\text { Traffic Typology } \\
\text { (demand) }\end{array}$} & $\begin{array}{c}\text { Minimum } \\
\text { values of } \\
\text { traffic } \\
\text { volumes }\end{array}$ & $\begin{array}{l}\text { Minimum } \\
\text { area that } \\
\text { it needs }\end{array}$ & $\begin{array}{c}\text { Storage } \\
\text { of full } \\
\text { load units }\end{array}$ & $\begin{array}{l}\text { Storage } \\
\text { of empty } \\
\text { load } \\
\text { units }\end{array}$ & Storing & $\begin{array}{c}\text { Decomposition } \\
\text { and } \\
\text { composition } \\
\text { of the goods }\end{array}$ \\
\hline$\frac{20}{2}$ & $\begin{array}{l}\text { Remote unit } \\
\text { loads }\end{array}$ & $\begin{array}{l}\text { Particular } \\
\text { goods that } \\
\text { need ad hoc } \\
\text { areas and } \\
\text { services }\end{array}$ & \begin{tabular}{||c} 
Minimum \\
productiveness \\
(in 270 days)
\end{tabular} & $\begin{array}{c}\text { Indication } \\
\text { of } \\
\text { minimum } \\
\text { threshold } \\
\left(\mathrm{m}^{2}\right)\end{array}$ & - & - & - & - \\
\hline 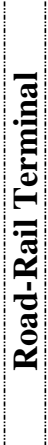 & $\begin{array}{c}\text { National and } \\
\text { International rail } \\
\text { and road traffic: } \\
\text { swap bodies and } \\
\text { maritime } \\
\text { containers }\end{array}$ & $\begin{array}{c}\text { Storing and } \\
\text { maintenance } \\
\text { area for } \\
\text { maritime } \\
\text { containers; an } \\
\text { area for road } \\
\text { transport } \\
\text { companies; } \\
\text { management } \\
\text { centre; parks: } \\
\text { it is open } 24 \mathrm{~h}\end{array}$ & $\begin{array}{c}8 \text { couples of } \\
\text { trains every } \\
\text { day }(110,000 \\
\text { UTI every } \\
\text { year })\end{array}$ & $\begin{array}{c}>500,000 \\
\mathrm{~m}^{2}\end{array}$ & $\begin{array}{l}\text { Yes, with } \\
\text { areas } \\
\text { equipped } \\
\text { for } \\
\text { particular } \\
\text { goods } \\
\text { (chemical, } \\
\text { soft goods } \\
\text { etc.) }\end{array}$ & $\begin{array}{l}\text { Yes, all } \\
\text { services }\end{array}$ & $\begin{array}{c}\text { Yes, in } \\
\text { specialised } \\
\text { areas }\end{array}$ & $\begin{array}{c}\text { Yes, with } \\
\text { specialised } \\
\text { warehouses }\end{array}$ \\
\hline 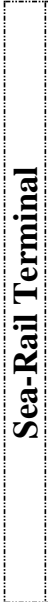 & $\begin{array}{l}\text { Traffic with } \\
\text { maritime origins } \\
\text { and destinations } \\
\text { with a change of } \\
\text { transport mode } \\
\text { for forwarding } \\
\text { by rail to } \\
\text { domestic and } \\
\text { international } \\
\text { destinations for } \\
\text { long distance: } \\
\text { predominance of } \\
\text { sea containers } \\
\text { over swap } \\
\text { bodies }\end{array}$ & $\begin{array}{l}\text { Storing and } \\
\text { maintenance } \\
\text { area for } \\
\text { maritime } \\
\text { containers; it } \\
\text { is open 24h }\end{array}$ & $\begin{array}{c}4 \text { couples of } \\
\text { trains every } \\
\text { day }(55,000 \\
\text { UTI every } \\
\text { year) }\end{array}$ & $\underset{\mathrm{m}^{2}}{>200,000}$ & $\begin{array}{c}\text { Yes but } \\
\text { only to } \\
\text { wait ships } \\
\text { and trains }\end{array}$ & $\begin{array}{l}\text { Yes, all } \\
\text { services }\end{array}$ & $\begin{array}{l}\text { Yes, but it } \\
\text { is only } \\
\text { temporary } \\
\text { and for the } \\
\text { area close } \\
\text { to port } \\
\text { hinterland }\end{array}$ & No \\
\hline
\end{tabular}

\subsection{Rail Freight Yards}

Rail freight yards - also called shunting yards - play an important role in railway freight operations. Their main function is to uncouple trains and reassemble them according to their common destinations (Marinov and Viegas, 2011). The shunting process takes about 10-50\% of the total transit time of trains. Hence the performance of these yards influences the quality 
of railway freight network operations. One of the main characteristics of rail freight yards is that the load itself is not moved from one train to another (Boysen et al., 2012).

Shunting yards are used for freight and passenger trains. The tasks for both types are similar whereas the number of wagons for passenger trains is not as high as for freight trains. Another aspect is that single units of passenger trains can be able to self-propelled (Boysen et. al., 2012). Because of the concentration for railway freight operations in this chapter the passenger tasks are not considered. Figure 4 shows a possible sequence of railway freight operations regarding the rail freight yards from sender to receiver. As one can see it is possible to cascade shunting yards. These cascaded shunting yards are grouped together in different categories according to their position in the sequence. (Ricci, 2012)

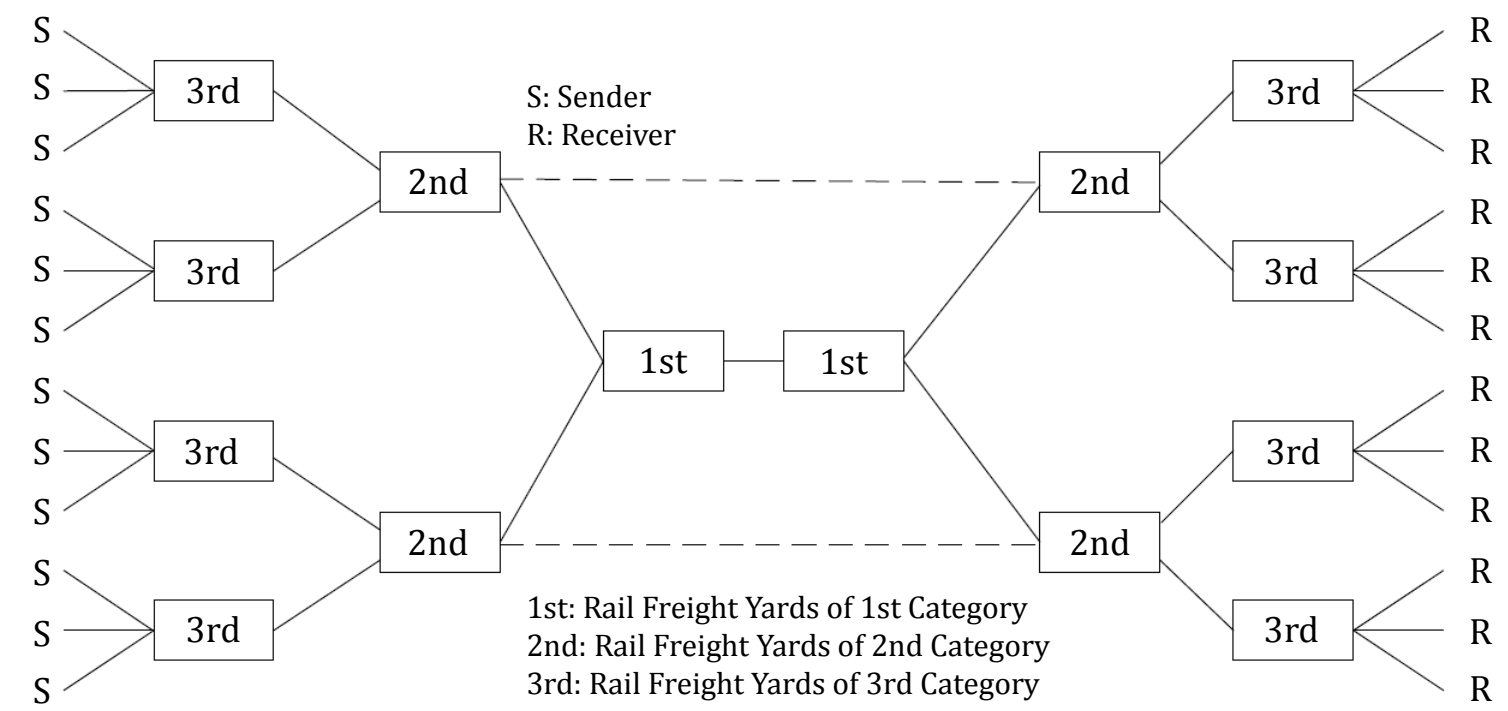

Figure 4 - Possible sequence of the railway freight operations (own graphics)

Yard capacities are determined by the number of parallel tracks (Boysen et. al., 2012). Because of the limited and expensive space for yards it is more important to look for options to manage these tracks than to add more tracks.

There are three different types of yards: (Marinov and Viegas, 2009)

I. Flat-Shunted Yards;

II. Hump Yards;

III. Gravity Yards; 
Because of the similarities between the tasks of hump and gravity yards they can be grouped together. Each of these yard types may have different characteristics which will be described in the next two subchapters.

\subsubsection{Flat-Shunted Yards}

Flat-Shunted Yards by definition are the yards in which the tracks lead into a flat shunting neck at one or both ends of the yard where the freight cars are pushed and pulled by a shunting engine which sorts them into the assigned track (Marinov and Viegas, 2009).

The push-pull method is employed in flat yards where the whole layout is built on level ground. This is the simplest arrangement, but it also turns out to be more costly to operate as the shunting engine continually moves up and down while sorting is in progress.

If the level of traffic passing through the station is low the general procedure would be to adopt a flat yard design, combining the reception and departure yards into one unit.

Figure 5 illustrates such an example. This flat yard has separated up and down yards, each made up of reception-cum-departure lines and sorting lines which are dead end sidings. Once a train is formed in the sorting area it is shunted to the reception-departure yard where it awaits departure. Often a flat-shunted yard is attached to a passenger station (Bhalerao, 2008).

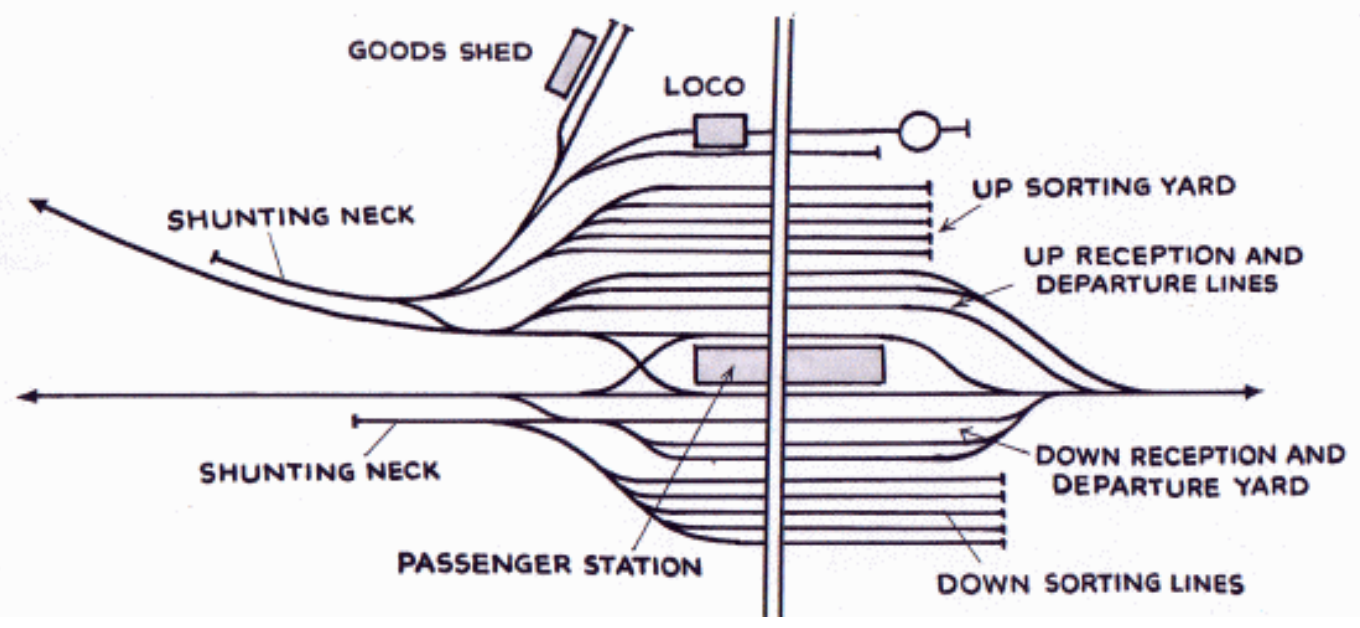

Figure 5 - Typical layout of a flat-shunted yard (Bhalerao, 2008)

Sufficient sustained handling capacity is a prerequisite for ensuring high performances and also to allow high capacity and preventing the terminal becoming a bottleneck (the arrival 
process is the fundamental external reason for malfunctioning of yards, together with the possibility that a train may be not dispatched under-loaded (Bhalerao, 2008).

\subsubsection{Hump/Gravity Yards}

The largest and most effective type of yards is the hump yard. At this type of yard the wagons of a complete train will roll down an incline to get reassembled for their departure. To achieve this kind of process the yard must have a specific layout. Hump yards consist of four different components: the receiving yard, hump, classification yard, departure yard (Yagar et. al., 1982). Figure 6 shows a typical layout of a hump yard including the four different components.

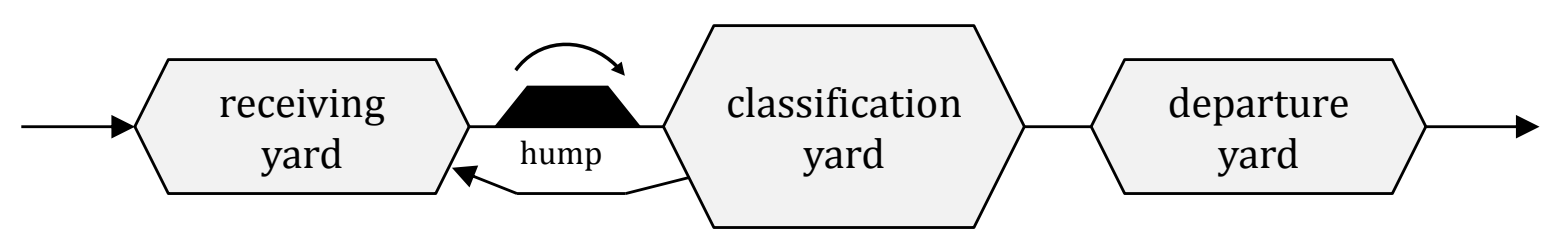

Figure 6 - Typical layout of a hump yard (own graphics, based on Marton et. al., 2009)

When inbound trains arrive at the receiving tracks, they will undergo an inspection. Afterwards, all trains are tagged with a destination code. Furthermore, the locomotives are uncoupled and move to refuelling platform (Lin and Cheng, 2011). After this process the wagons are queued on the receiving track until they will get on top of the queue (Assad, 1980). These trains are now gradually pushed up the hill by an engine. While rolling down this hump by gravity the individual cars are uncoupled and get into the classification yard (Marinov and Viegas, 2009). The cars with common destinations are queued there while reassembling. This process is performed by specific shunting engines. As one can see in Figure 6 the classification tracks can be connected with the receiving tracks for a repeated shunting (Boysen et. al., 2012).

The last step in this process is that the trains will be prepared for departure. A loco has to be set in front of the wagons and the train has to wait until departure. Finally the train departs (Ricci, 2012).

There are also exceptions to the typical layout shown in Figure 7. Some yards just have the hump and classification tracks while others have an additional hill at the other side of the 
yard. There is also the possibility that the shunting yards have this additional hump parallel to the existing one. Some kind of other yards have a single end classification bowl. The last three types of rail freight yards are shown in Figure7 (Marton et. al., 2009).

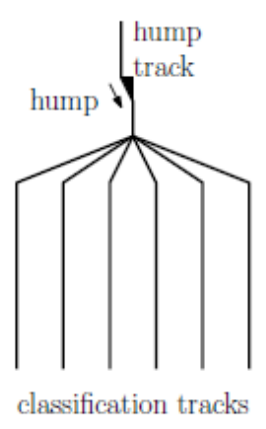

(a) single-ended yard

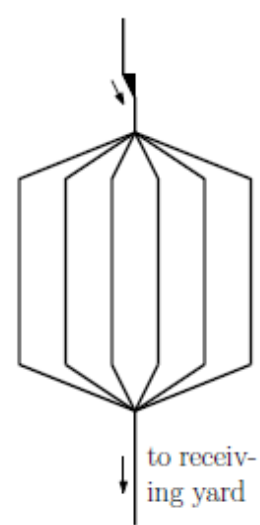

(b) double-ended yard

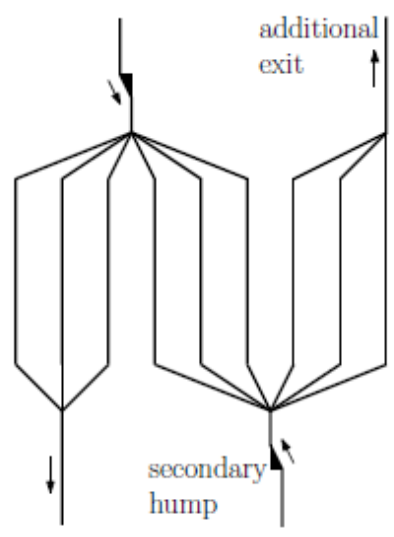

(c) advanced layout

Figure 7 - Common variants of classification bowl layouts (Marton et. al., 2009)

The gravity yards operate in the same way but there are topographical differences. A gravity yard needs a natural slope that the trains are rolling down this slope themselves without the usage of an engine and be sorted on the classification tracks.

\subsubsection{Comparison between Rail Freight Yards}

Comparing the two types of rail freight yards it is visible that the two kinds of gravity yards need less usage of engines (Marinov and Viegas, 2009). The wagons are shunted with the help of gravity and therefore it is no need for special shunting engines. There is only the need of one engine to push the wagons on top of the hump. The gravity yards are even cheaper because of the natural topography.

According to the natural topography it is cheaper to build a gravity yard than a hump yard. When the topography allows building a gravity yard it is only required to install tracks for the shunting process. A manmade hill has to be raised for a hump yard, which is cheaper than building a complete gravity yard with its incline. 
But one important fact is that the hump yards require more staff, for example, to set the breaks (Boysen, 2012). Therefore the investment costs for the hump have to be compared to the staff costs.

A problem at hump yards could be the hump itself. When the amount of humps is not as big as the amount of switch engines the hill becomes a bottleneck. Therefore a good management is required thereby the trains do not have to wait that long. This problem can also occur when there are less pull-out tracks than yard engines (He et. al., 2003).

At least the hump yards are the largest and most effective classification yards. They have the largest shunting capacity, too. It could be about several thousand of wagons a day (Marinov and Viegas, 2009). Therefore, hump yards should be preferred.

In the following table it is summarised all the considerations about the two types of rail freight yards.

Table 5 - Comparison between Rail Freight Yards

\begin{tabular}{c||cc} 
& Flat-Shunted Yards & Hump/Gravity Yards \\
\hline Effectivity & - & + \\
$\begin{array}{c}\text { Need for traction } \\
\text { locomotives }\end{array}$ & + & - \\
Staff required & + & Hump/Topography \\
Requirements & Engines & Hump \\
Bottleneck & Shunting Neck &
\end{tabular}




\section{Opportunities for Improvement in Operating Practice and Yard Infrastructure}

This part refers to some improvements in terms of infrastructure and operations. They are presented in accordance with their time frame completion.

\subsection{Short Term}

For a short period of time, the improvements that are proposed to be implemented, do not require high investment costs and long time consuming processes.

The companies that are responsible for the operation of either passenger stations or freight terminals need to focus on the improvement of the human resource management. A lifelong learning process is crucial because of the continuous change of the environment and technology. The personnel also, need to be motivated on a daily basis in order to improve their performance and reduce mistakes.

To improve the dwell time of trains at stations, it is important that passenger circulation is as efficient as possible. This means that trains should have the appropriate number of entrance and exit points. Moreover, the platforms should be of the right dimensions, and their accesses should have automated systems as escalators, "travelators" and lifts to ensure a good mobility of passenger flow.

Furthermore, an improvement which is applicable to intermodal or rail freight terminals is the installation of automatic code readers that do not require human support (Figure 8). As a result, the wagons can be identified in an automatic way, which is faster and contributes greatly to the reduction of the operational costs. Also as a result, the level of service is improved and a continuous information through a common network accessible to all customers could be provided, which in turn, can also grant more control of freight theft. 


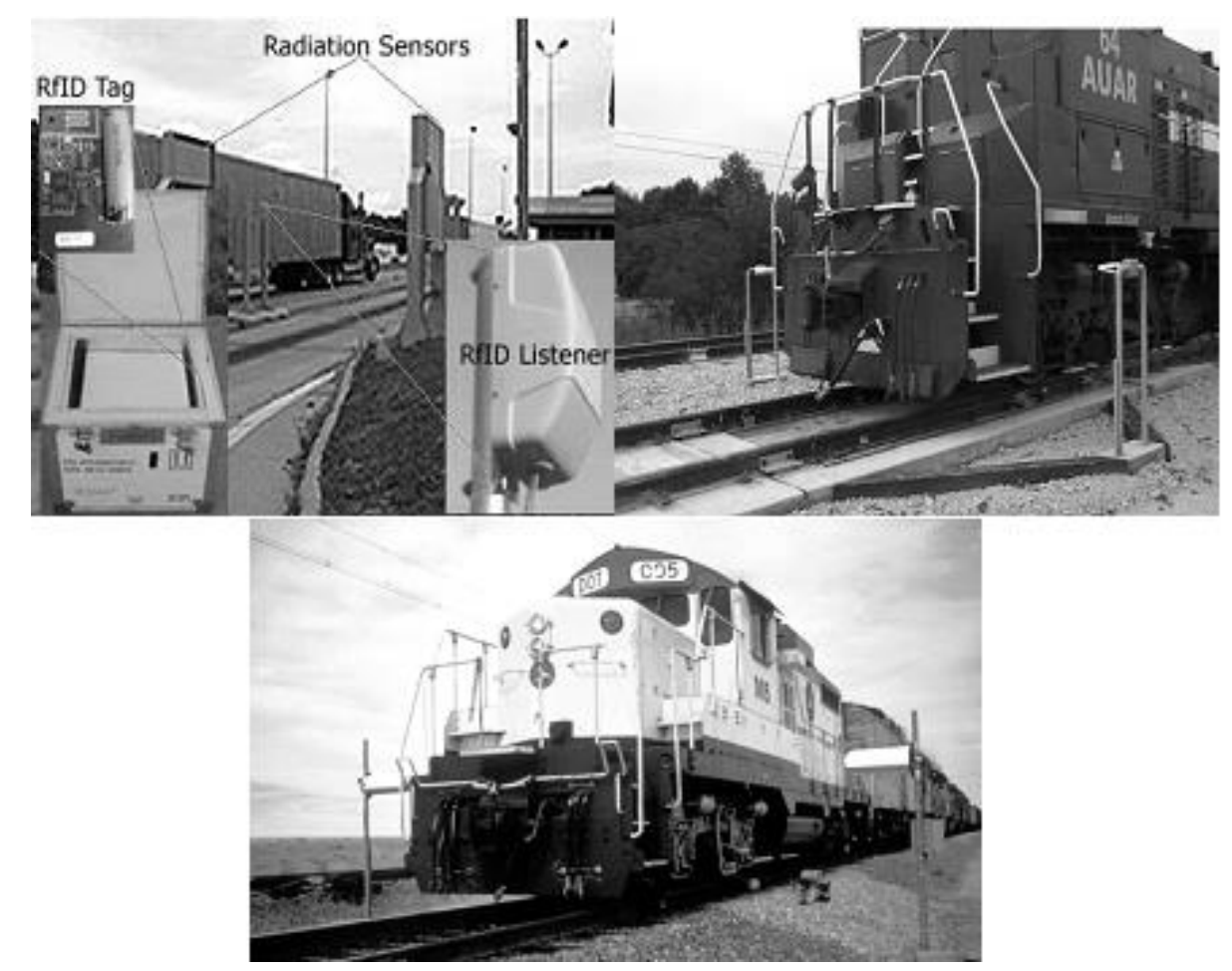

Figure 8 - Examples of automatic readers that can be installed for rail and road transport (Source: www.railway-technology.com, accessed on 29 July 2013)

\subsection{Medium Term}

In a medium term timeframe, investments and improvements can be performed, but no revolutionary developments are invented.

For passenger stations, the train control centres need to be upgraded with new technologies, so they can handle routine problems like train dispatching and transit conflicts in a more efficient way. What is more, the upgrade of signalising system is a key factor in order to increase capacity and performance of passenger stations. By doing such, the gap between trains will decrease, which means more trains can circulate on the network, which in turn means, not only more passengers transported but also more freight. The appliance of ERTMS level 3 could contribute greatly towards this direction. 
In particular for rail freight terminals, the operational flexibility plays the most important role. Innovative transhipment operations enable the direct load and unload operations from the truck to the train and vice-versa. Few examples of these technologies are Cargo Beamer, Cargo Mover, Modalohr and Mobiler.

IT (Information Technology) systems have already been implemented, but the systems need to be improved on a regular basis because of the continuous technological developments. In addition, the adoption of up-to-date IT systems promotes the increase of data exchange in terms of quantity and quality between the different stakeholders. The most relevant applicable technology is the EDI (Electronic Data Interchange) which coordinates the information flow between different companies.

The train assembly (pull-down) process has been identified as the bottleneck in a majority of classification yards. A sensitivity analysis conducted on three bottleneck management alternatives suggests that pull-down capacity can be increased compared to the baseline case without large labour or capital expenses, through better management of the process and its interactions with the system. To maximise efficient use of rail yard infrastructure and resources, more emphasis should be placed on the quality of the classification process, rather than on quantity (Dirnberger and Barkan, 2007).

According to the comparison of rail freight terminals given in subchapter 1.3.III, the hump yards of the future should be continuously improved. One of these improvements concerns the management and organisation of the yard. Because of the different possible bottlenecks, the incoming or outgoing wagons have to be dispatched near the mathematical optimum in order to avoid inefficiency and waiting times. Therefore, the organisation of the wagons has to be adapted to the current situations. In addition, Operational Research can conduct tests of different types of yard layouts in order to achieve higher yard performance.

Some older sea-rail terminals have the rails aboard dock. In modern general cargo terminal they are forecast to railroad tracks on board dock, due to the large losses of time that are encountered in the load of railway wagons, and due to the displacement of the carriages themselves during the loading phase. In addition, the presence of the train stops completely cross-connection along the dock. So a possible improvement would be to place the beams of 
binary of the old terminals away from the dock, preferably along the side of the square farthest from the side of dock, or the warehouse or the deposit.

In the following table, some of the most important improvements are summarized

Table 6 - Some of the most important Medium-term improvements

\section{Medium-term improvements}

- New technologies in the train control and signalizing systems to avoid human mistakes

- Innovative transhipment technologies (Cargo Beamer, Cargo Mover, Modalohr)

- Increase of containers traffic: areas reorganisation to prevent the bottleneck effect

- Shifting the balance between modes of transport

\subsection{Long Term}

In a long term time period, it is considered that the improvements proposed need a long time to develop, have high investment costs or are revolutionary and can be translated as guidelines for the future.

One of these revolutionary ideas can be a unique terminal developed for serving both passengers and freight at the same time. Currently this is difficult to be applied, but taking under consideration the gradual development of the transported goods, it will be possible to connect these two different parts of railway. Because of the less heavy and more palletised goods, heavy cranes and such equipment will not be necessary anymore. To follow the lead of Berlin Hauptbahnhof, the different types of rail traffic will be served in multiple levels. For example, the freight rail could be located at the basement of the station, while the passenger station is designed on ground floor so that emissions, noise and vibrations are minimised or attenuated. Another positive aspect is that there would be only one terminal instead of two. In this way the saved space could be used for other uses. Nevertheless, the viability of the area has to be considered in anticipation of the increased traffic due to the existence of a double function in this terminal. 
Nowadays, the trend is towards sustainability and renewable energies. To achieve the aspects of these two objectives, BREEAM (Building Research Establishment Environmental Assessment Method) can be implemented. The implementation of BREEAM standard provides a concise framework for identifying and implementing practical and measurable green building design, construction and maintenance solutions that reinforce the efficiency.

Another important issue regards the development of the automation level. Since the personnel are getting more expensive and machines cheaper, researchers try to improve the terminal equipment for the highest possible degree of automation. If the processes at a yard or terminal are automated, the efficiency rises. Certainly, personnel are required to supervise the machinery, but with the developers' assistance, staff can be optimised.

\section{Conclusion}

Concerning the expected occurrence of railway traffic, the very first step towards the implementation of improvements that aim to increase the level of terminal performance is to make a clear distinction between the different types and respective demands of stations, terminals and yards. This is why it was considered necessary to analyse the operability, as well as the differences between them. Besides, the ongoing developments that occur and affect the quality of the transported traffic volume should not be underestimate.

The railway sector should take immediate action in order to maintain and even improve its competitive positioning in the transport market. The improvement opportunities analysed in the second part of this paper, are intended as guidelines to specific improvements to be developed.

An issue of great importance is to turn the future of the railway transportation into a high priority issue for the EU and the national governments. A central plan that sets clear priorities and a timeframe for infrastructure, operational, as well as management developments would be the key for a new generation in railway transportation. 


\section{Acknowledgements}

This paper was written within the framework of the Intensive Programme in Rail and Logistics, cofunded by Lifelong Learning Programme of the European Commission, and delivered at the University of Newcastle upon Tyne under the directions of the NewRail Research Centre. The authors express their sincere thanks to Ms Anna Fraszczyk for her unreserved guidance and support.

\section{References}

AGORA (2012) Intermodal terminals, webpage: www.intermodal-terminals.eu.

Assad, A. (1980) Models for rail transportation. Transportation Research, Part A, vol. 14, pp. 205220.

Bhalerao, R. (2008) Exploring India's Marshalling Yards. Available at www.irfca.org.

Boysen, N., Fliedner, M., Jaehn F. and Pesch, E. (2012) Shunting yard operations: Theoretical aspects and applications. European Journal of Operational Research, vol. 220, pp. 1-14.

Clausen, U. (2011) Logistik - und Verkehrsmanagement: ÖPNV I. Dortmund: ITL TU Dortmund.

Girolamo, P. (2012) Costruzioni marittime. L'Aquila: Università degli Studi dell'Aquila.

Dirnberger, J., and Barkan, C. (2007) Lean Railroading for Improving Railroad Classification Terminal Performance: Bottleneck Management Methods.

Feldman, R., and Gross, M. (1996) Transportation Expressions, Washington, DC: Bureau of Transportation Statistics, U.S. Department of Transportation.

Global Security (2012) Lift-on/Lift-off (LO/LO) Ships, webpage: www.globalsecurity.org.

He, S., Song, R., and Chaudhry, S. S. (2003) An integrated dispatching model for rail yards operations. Computers and Operations Research, vol. 30, pp. 939-966.

European Union (2012) Il modello per la gestione dei containers, webpage: www.epractice.eu.

Lin, E., and Cheng, C. (2011) Simulation and analysis of humpyards in North America. Proceedings of the 2011 Winter Simulation Conference, Atlanta, USA.

Marinov, M., and Viegas, J. (2009) A simulation modelling methodology for evaluating. Simulation Modelling Practice and Theory, vol. 17.

Marinov, M., and Viegas, J. (2011) Analysis and Evaluation of Double-Ended Flat-Shunted Yard Performance Employing Two Yard Crews. Journal Transport Engineering, vol. 137, pp. 319326.

Marton, P., Maue, J., and Nunkesser, M. (2009) An Improved Train Classification Procedure for the Hump Yard Lausanne Triage. 9th Workshop on Algorithmic Approaches for Transportation Modeling.

Middendorf, D. (1998) Intermodal Terminals Database: Concepts, Design, Implementation, and Maintenance, Washington, DC: Bureau of Transportation Statistics U.S. Department of Transportation. 
Musso A. (2010) Progetto di Terminali ed Impianti di Trasporto, Chapter 2. Rome: Sapienza Università di Roma.

REFER - Rede Ferroviária Nacional, EPE (2008) Lisbon: REFER.

Ricci, S. (2012) Rail Terminals. Newcastle upon Tyne: RailNewcastle.

Rodrigue, J., Slack, B., and Comtois, C. (1998) Transport Geography on the Web, New York: Hofstra University.

Teixeira, P. (2011) Engenharia Ferroviária - Slides da cadeira. Lisbon: Instituto Superior Técnico.

Yagar, S., Saccomanno, F., and Shi, Q. (1983) An efficient sequencing model for humping in rail yard. Transportation Research, Part A, Vol. 17, n. 4, pp. 251-262. 